\title{
Venture Capital in Russia and the Global Evolution of Venture Capital
}

\author{
Eugenia L. Moreva*
}

\begin{abstract}
Deputy Director of the Institute of Industrial Policy and Institutional Development, Financial University under the Government of Russian Federation, Moscow, Russian Federation
\end{abstract}

\begin{abstract}
The Topicality: The Article is to identify the perspectives for the Russian venture capital development as an integral part of its global sector.

The Novelty: The Article provides the Analysis of the Russian venturing development in the lens of the Global Venturing evolution.

The Practical usefulness: The Analysis results with the determination of the content transformation of the global venturing, the Russian included, and provides the basics for its further efficient governance.
\end{abstract}

Keywords: Venture capital, business-angel, innovation, Venture capital fund, innovation capital.

In view of the global transition towards the innovation based society and economy the identification of the terms to mobilize and make use of capital recourses to facilitate the production and utilization of novelties is of extreme importance both for the theoretical and pragmatic reasons. Such a determination requires the venture capital (VC) sector performance investigation being the latter the one to provide both funds and competences for the entrepreneurs' innovations activity (Mason, 2009).

The VC industry tended consolidating and proliferating over the world since the 70 s of the last century providing thus a good basis for its conceptualization and accumulation of data adequate to monitor and provide the respective policies facilitating the advances of innovation development.

The patterns elaborated were applied in post-soviet Russia as well facilitating thus to judge the important element of national innovation ecosystem and to facilitate its progress. Until nowadays still not all the data treated commonly as the key VC indicators figure in the main issues of the principle national entities and stakeholders in charge or operating in the industry. Of the overall metrics of the VC amount and number of its entities, their investments in the country, the number of fundraising rounds, the average round size, average deal size, the number of VC general partners (GP) and its dynamics, the internal rate of return (IRR) and the difference between these and the analogues of other countries the national Russian Venture Capital

*Address correspondence to this author at 125993, Moscow, Leningradsky Prospekt, 49, r.140, Russia; E-mail: ELMoreva@fa.ru, eu7711460@mail.ru JEL classification codes: G24, O30, O10, O33.
Association discloses only a part which refers to the subjects of the market, their investments and exits (Table 1).

Despite the opportunities to get an idea of some VC industry's trends based on such an information one may question if it is enough to judge of the fundamental tendencies of Russian venturing against its global evolution.

The data proves a quite modest magnitude of the Russian VC sector compared with its analogues from USA and Europe, still to follow the former the dynamics of its foreign "mates". In spite of the too slight recuperation of the industry after the global crises of the late 00s and the sanctions imposed on the country in 10s the Russian sector tended following the trend of the evolution of the global VC. The information of the Russian entity correlated with that of other sources to identify the slight increase in the $2 d$ half of the 10 s of the number of $\mathrm{VC}$ funds by the new ones (averaging these from 22 to 28 per year in 2013-2017 and surpassing the number of the organizations liquidated these decreasing from the average of 17 in 2013 to 5 in 2017) (Sukharevskaya, 2017).

Since the further conceptualization of the state and opportunities of the Russian VC market requires a deeper level of analysis and the focus on its different components, the same as it occurs with the VC sector research in other countries, the special separate info of its major institutional and industrial components is accounted.

The data prove the structure of the sector varied for different institutional participants such as the Private and the Public segments with the former decreased 
Table 1: The Key Russian VC data

\begin{tabular}{|c|c|c|c|c|c|c|}
\hline Item & 2012 & 2013 & 2014 & 2015 & 2016 & 2017 \\
\hline \multicolumn{7}{|l|}{ Subjects of VC (Funds) } \\
\hline VC funds (mln.USD) & 3713 & 4635 & 4357 & 3834 & 3781 & 4071 \\
\hline Avarage fund (mln.USD) & 27,3 & 27,9 & 24,8 & 20,9 & 21,4 & 21,0 \\
\hline total amount of venture capital invested (mln.USD) & 376 & 285 & 150 & 150 & 125 & 125 \\
\hline the number of investments & 138 & 188 & 229 & 190 & 204 & 178 \\
\hline the average amount of investment (mln.USD) & 2,7 & 1,5 & 0,73 & 0,8 & 0,6 & 0,7 \\
\hline \multicolumn{7}{|l|}{ Exits } \\
\hline
\end{tabular}

Source: based on (RVCA, 2017).

Table 2: The Main Institutional Segments of the Russian VC Industry Public (State) /Private VC-Funds

\begin{tabular}{|c|c|c|c|c|c|c|}
\hline (mln. USD) & 2012 & 2013 & 2014 & 2015 & 2016 & 2017 \\
\hline Public (mixed) & 1651 & 1740 & 1539 & 1074 & 894 & 888 \\
\hline Total & 3713 & 4635 & 4357 & 3834 & 3781 & 4071 \\
\hline \multicolumn{7}{|l|}{$\% \%$} \\
\hline Private & $55,50 \%$ & $62,50 \%$ & $64,70 \%$ & $72,00 \%$ & $76,40 \%$ & $78,20 \%$ \\
\hline Total & $100,00 \%$ & $100,00 \%$ & $100,00 \%$ & $100,00 \%$ & $100,00 \%$ & $100,00 \%$ \\
\hline Units & 2012 & 2013 & 2014 & 2015 & 2016 & 2017 \\
\hline Public (mixed) & 45 & 49 & 52 & 57 & 53 & 54 \\
\hline Public (mixed) & $33,10 \%$ & $29,50 \%$ & $29,50 \%$ & $31,10 \%$ & $29,90 \%$ & $27,80 \%$ \\
\hline Private & $66,90 \%$ & $70,50 \%$ & $70,50 \%$ & $68,90 \%$ & $70,10 \%$ & $72,20 \%$ \\
\hline Total & $100,00 \%$ & $100,00 \%$ & $100,00 \%$ & $100,00 \%$ & $100,00 \%$ & $100,00 \%$ \\
\hline
\end{tabular}

Source: RVCA Yearbook 2017.

\section{Corporate/non-corporate VC funds}

\begin{tabular}{|c|c|c|c|c|c|c|}
\hline (mIn. USD) & $\mathbf{2 0 1 2}$ & $\mathbf{2 0 1 3}$ & $\mathbf{2 0 1 4}$ & $\mathbf{2 0 1 5}$ & $\mathbf{2 0 1 6}$ & $\mathbf{2 0 1 7}$ \\
\hline \hline Corporate & 471 & 436 & 423 & 410 & 532 \\
\hline Non-corporate & 3242 & 4199 & 3934 & 3424 & 3379 \\
\hline Total & $\mathbf{3 7 1 3}$ & $\mathbf{4 6 3 5}$ & $\mathbf{4 3 5 7}$ & $\mathbf{3 8 3 4}$ & $\mathbf{3 7 8 1}$ & $\mathbf{4 0 7 1}$ \\
\hline$\% \%$ & & & & $10,7 \%$ & $10,6 \%$ \\
\hline Corporate & $12,7 \%$ & $9,4 \%$ & $9,7 \%$ & $13,1 \%$ \\
\hline
\end{tabular}




\begin{tabular}{|c|c|c|c|c|c|c|}
\hline Non-corporate & $87,3 \%$ & $90,6 \%$ & $90,3 \%$ & $89,3 \%$ & $89,4 \%$ & $86,9 \%$ \\
\hline Total & $100,0 \%$ & $100,0 \%$ & $100,0 \%$ & $100,0 \%$ & $100,0 \%$ & $100,0 \%$ \\
\hline Units & 2012 & 2013 & 2014 & 2015 & 2016 & 2017 \\
\hline Corporate & 16 & 21 & 20 & 17 & 15 & 17 \\
\hline Non-corporate & 120 & 145 & 156 & 166 & 162 & 177 \\
\hline Total & 136 & 166 & 176 & 183 & 177 & 194 \\
\hline \multicolumn{7}{|l|}{$\% \%$} \\
\hline Corporate & $11,8 \%$ & $12,7 \%$ & $11,4 \%$ & $9,3 \%$ & $8,5 \%$ & $8,8 \%$ \\
\hline Non-corporate & $88,2 \%$ & $87,3 \%$ & $88,6 \%$ & $90,7 \%$ & $91,5 \%$ & $91,2 \%$ \\
\hline Total & $100,0 \%$ & $100,0 \%$ & $100,0 \%$ & $100,0 \%$ & $100,0 \%$ & $100,0 \%$ \\
\hline
\end{tabular}

\section{Seed / not-seed VC funds}

\begin{tabular}{|c|c|c|c|c|c|c|}
\hline (mln. USD) & 2012 & 2013 & 2014 & 2015 & 2016 & 2017 \\
\hline Seed & 258 & 498 & 536 & 422 & 403 & 432 \\
\hline not-seed & 3455 & 4137 & 3821 & 3412 & 3377 & 3576 \\
\hline \multicolumn{7}{|l|}{ Units } \\
\hline Seed & $7,0 \%$ & $10,7 \%$ & $12,3 \%$ & $11,0 \%$ & $10,7 \%$ & $10,8 \%$ \\
\hline Units & 2012 & 2013 & 2014 & 2015 & 2016 & 2017 \\
\hline Seed & 21 & 28 & 36 & 35 & 33 & 39 \\
\hline not-seed & 115 & 138 & 140 & 148 & 144 & 153 \\
\hline Total & 136 & 166 & 176 & 183 & 177 & 192 \\
\hline Total & $100,0 \%$ & $100,0 \%$ & $100,0 \%$ & $100,0 \%$ & $100,0 \%$ & $100,0 \%$ \\
\hline
\end{tabular}

Source: (RVCA, 2017).

Table 3: Industrial Structure of the Russian VC Funds' Investments

\begin{tabular}{|c|c|c|c|c|c|c|}
\hline Segment & $\mathbf{2 0 1 2}$ & $\mathbf{2 0 1 3}$ & $\mathbf{2 0 1 4}$ & $\mathbf{2 0 1 5}$ & $\mathbf{2 0 1 6}$ \\
\hline \hline ICT & $56,0 \%$ & $53,0 \%$ & $52,0 \%$ & $51,0 \%$ & $53,0 \%$ & $55,0 \%$ \\
\hline Mixed & $35,0 \%$ & $35,0 \%$ & $35,0 \%$ & $34,0 \%$ & $34,0 \%$ & $32,0 \%$ \\
\hline Real & $10,0 \%$ & $12,0 \%$ & $14,0 \%$ & $15,0 \%$ & $13,0 \%$ & $13,0 \%$ \\
\hline Total & $100,0 \%$ & $100,0 \%$ & $100,0 \%$ & $100,0 \%$ & $100,0 \%$ & $100,0 \%$ \\
\hline
\end{tabular}

Source: RVCA Yearbook 2017.

against the latter in the current decade and its size diminishing. Its average amount decreased from 37 $\mathrm{mln}$. USD in 2013 to $16 \mathrm{mln}$. USD in 2017 against more stable amount in the Private segment.

The state of the structure of Corporate \ Noncorporate funds kept much more variable with the correlation between their average sizes to be more or less similar over the period. The same is true for the stages specialization of the funds and their industrial focus (Table 3).

The Russian VC market doesn't contradict radically to the dynamics of foreign one with the ICT segment being the most preferred (Moreva 2012a, 2012b, 2013). The others differed somehow since in North America and Europe the Health care and the Cleantech dominated, while in Russia it was the Real sector and 
the Mixed. Such a similarity between the Russian VC and that of other economies provided the opportunity to judge the first one in lens of the global venturing evolution.

Meanwhile the structure of the industrial profiles on the latter went transforming. The ICT-focused segments being capital light and scalable attracted more and more VC investors. The funds move away from more capital-intensive businesses of hardware and materials to invest in capital-light segments, mostly the software-enabled devices.

On the contrary the Cleantech segment which looked quite attractive some 5 years ago and mobilized a large quantity of state funds in some countries actually provided too low returns if compared with ICT and other sectors. For example, in Canada its 10 and 5 years gross IRR average was $3-6$ times and 2,5 - 3 times lower respectively (Canada's, 2017). Such a gap tended becoming more and more pronounced to impact the re-allocation of capital between the sectors.

In Healthcare the strong capital constraints of the segment made the VC to concentrate in productfocused companies (e.g. the biotech firms that develop a single family of molecules) with a single path to liquidity (acquisition) and limited growth opportunities. And in the very biotech businesses the high capital requirements stimulated the integration of various types of stakeholders for the VC activity incorporating in such a platform the state, universities, research institutes and other national and international stakeholders, foreign investors primarily.

With this the state began playing an important role initiating various programs and projects in different segments of VC. For example, in Canada one of the prominent cases is the Pan-Canadian Artificial Intelligence Strategy in Canada, $\$ 125$ million, issued to support directly the research and talent development in the canadian sector it to become a global leader. The Strategy incorporated the foreign participants with, for example, American Microsoft and Google to set up Al research centers in the country and acquiring its top talents and contributing funds to other Canadian Al initiatives (the Montreal Institute for Learning Algorithms, The Vector Institute in Toronto, etc.).

Such transnationalization made the sector more sophisticated and complicated object of analysis aggravated the latter with the overall tendency of the increase in number of new companies classified at the intersection of major sectors (e.g., a healthcare and IT). In large scale such a trend was due to the broad application of information and communication technologies (ICT) in different economic areas due to their ability to generate, interpret and derive insights from data and its management to become a core competency in various (if not all) sectors of economy.

Combined with the intensive development of new subsectors related to the artificial intelligence (Al), the Internet of things (IOT), Fintech, Big Data and others related to the general Economy's Digitalization trend they provided the new characteristics to the firms' performance and changed their business-models.

The transformation of the main subjects of VC relationship impacted the strategies of the latter. Among the new one appeared a "spray and pray" investment approach. With it the investors managed to provide a limited funding and governance to an increased number of ventures which they were more likely to abandon. Meanwhile the initial experiments issued significant information about the potential of the project making its cheaper and quicker.

These changes led to a rise in the number of innovations not related to the complex technologies with their costly and risky initial experiments and the entry of new financial intermediaries. The changes also made the potential portfolios companies to demonstrate more progress before the first financing and provoked new modes of exits to assure a higher rate of successful ones reflected with the higher values of the indicator of exit frequency (total companies exited in a given year divided by the total number of companies having received funding).

The proliferation of new phenomenon facilitated also a shorter time to mobilize funds and the substitution of the former patterns of venturing when a couple of large exits of portfolio companies drove all of the fund's return, breaking a traditional VC model and changing the marketplace.

The exits which required more time tended suspended by the more economic (via an acquisition rather than an IPO); the corporations becoming more involved and aligned with the start-ups overcoming the differences of their productive specialization (i.e. if they operate in different sectors). They reoriented more and more towards greater collaboration with state development institutions, networked with start-ups not only in financial sphere (funding, tec.) but in various 
professional, business and consumers' associations and other organizations.

Under such terms the traditional VC funds were either to be enlarged to be able to overcome the new time and capital requirements of early stage companies or to become smaller to follow the new strategies and invest in later stage companies. Such a differentiation was intensified with the globalization tendencies and the entry of foreign VC and/or multinationals. Their contribution for the further advances of the innovations were drawbacked by the higher risks of the transfer of the most promising start-ups from the motherland to another jurisdictions.

In Russia the similar trends were limited by the specific national economic, cyclical and political factors translated in economic depression, ruble depreciation, sanctions and others. They aggravated seriously the integration of the Russian VC in the world economy, stipulated the outflow of foreign funds from the country in time of crisis limiting thus the contribution to the national financial, economic and professional networks, competences and expertise.

In such a situation the Russian government supported not only the very VC industry participating in it both in a direct (investing in venture funds and funds of funds) and indirect ways (fiscal measures and others) but by means of its general strategic performance to emancipate the whole ecosystem, stimulate national digitalization and other measures.

Such a performance impacted mostly the large national corporations which increased their investments in start-ups to get their profit by means of repurchasing, the economies of R\&D costs, etc. In 2017 the largest State corporations Roscosmos, Rosatom and some others declared the foundation of their proper VC funds. They expected the projects' suppliers to be interested in their VC models to get capital and new competences to apply them in the venture ecosystem.

Such a performance was stimulated also by the advances in the technologies and scientific area. The opportunities related facilitated the start-ups to expand not only into the typical venturing industries but also to those not attractive for them before, - i.e. of primary and infrastructure sectors to catch up with the digitalization in production and environmental servicies (blockchain and others).

The new patterns stimulated the incorporation in venturing processes the new stakeholders, i.e. the private investors, commercial banks and others to serve the local operations of the new start-ups in the segments familiar to them. Their efforts made possible the development of the new types of organization for the intensive early development such as crowdfunding platforms, ICO and other radically different from the traditional VC models and processes in terms of due diligence economies, the ownership structure alternatives, etc. This was a novelty for traditional VC development transforming it for the sake of new larger rounds more flexible appraisal of VC in different stages.

From one point of view the changes looked to support the consolidation of the new forms. From the other they limited the reproduction of the traditional VC making it to make new organizational forms. This threated disbalancing the conjunction of the stages of evolution of their portfolio companies and weakening the advances of later stages impacts and respective returns

In difference of other countries in Russia such a conflict was partly counterbalanced by the low wages of Russian IT- and other professionals (e.g. cheap price of national human capital), which partly blocked the digitalization and the related knowledge transfer and its impacts. These circumstances made it difficult to appraise effectively the state of VC to decide for the provisional distortion or for a specific form of the new stage of its overall evolution.

Meanwhile the latter has become an object of special analysis of various scholars. They stressed the newest trends in the VC funds' performance with respect to their size, industrial specialization; stage specialization; team experience; capital origin and other translating them in such regularities as the higher returns of the funds with narrow industrial scopes than those of the generalist funds; the better performance of the later-stage VC funds than the early-stage; their more experienced teams overperforming the others; the US-based VC funds outperforming the Europeans'; funds raised in boom times generate lower returns compared to others, etc.

The initial conceptualization of its basics was formulated in terms of so called 'VC math problem' when the amount of exit values generated to provide a minimum return from VC fund investing appeared to be significantly lower than the real one determined over a pronounced period. Thus the limited supply of attractive investment opportunities, - 'money chasing deals' phenomenon, - provoked the decrease of the returns 
("Shrinking exit markets") and the collapse of the European and American stock markets as occurred in the post- 'dot com' crises (Block, J. \& P. Sandner, 2009). If not for the proliferation of the smaller and weaker portfolio companies and their modest exits the only option would have been some radical transformation of the sector it not to downsize radically (Wilson, 2009; Kedrosky, 2009).

Further on the fundamentals of the phenomenon were articulated in terms of advances in the basic technologies of the industrial segments traditionally treated as the main object of VC operations confirming partly the historical economic overview at the beginning of the article.

In the ICT sector the progress of the Internet-related services and the open source technologies made the startup costs radically lower in comparison with a decade ago. It impacted the shorter timespan, reduced expenses for hardware, limited marketing and distribution costs due to easier access to cheaper international labor markets in great scale. The options appeared were translated in new pricing models with the respective decrease of financing needs of start-ups able to be met by business angels rather than by $\mathrm{VC}$ funds.

The adverse trend in the life science sector was caused by the increase of the time of drug development which contradicted the traditional 10-year structure of VC funds and forced them to reorient for the later phases or for the medical technologies segment. The same was the case of the other family segments of biotechnologies in which the times to liquidity increased considerable making many $\mathrm{VC}$ firms to extend their life beyond 10 years and provoking the negative impacts on their IRR (Greene \& Purcell \& all 2010; Segalla, Rouzies \& Ghalbouini, 2010).

The other case were the clean tech investments which appeared to be actually channeled to the infrastructure area and not to the scalable new technologies. Under such circumstances the debt funding appeared to be much more adequate as a funding source than the VC mobilization.

The tendencies resulted in the overall decrease of the VC returns and the split of the sector in two large subgroups.

One was of the top quartile of the total VC funds sector, primarily the US. It was not numerous but with perfect returns. The mega $\mathrm{VC}$ funds of the group were run by the most experienced and successful VC firms and the institutional investors were pegged to the very top VC names.

Another group was integrated by the rest of the funds, i.e. of many smallish organizations oriented mostly for various Internet-based businesses. Since these were with low operating costs their capital efficiency required their highly flexible performance, i.e. to keep seeking the opportunities for quicker exits through small trade sales. Against the new realities the small format of VC funds resulted reasonable and successful.

Meanwhile those stick to the traditional model tended to be eliminated by the intensification of the GPs performance and their excessive fee levels in expense of limited partners' (LP) negatively impacting them and making them to write down their holdings and to abandon the VC assets class. The same situation occurred with the middle group of VC funds applied to the traditional model which ended to be greatly reduced quantitively and qualitatively (Gobry, 2011).

Followed by the similar changes in the other nonhigh-tech sectors the overall financial demand for the capital to finance entrepreneurs' innovations activity favored the investment and working models modification due to the lower amounts of capital (per deal) requirements, its new institutional patterns and organizational forms, changes in and shifts in investor base.

Thus, the former caused the new sources of funding mobilization with the respective changes of the relationship with the start-ups and the new working principles. The latter stimulated the efficiency reconceptualization in lens of various market dynamics and renewed needs of investors; the focus on various options of financing (incl. raising capital) optimization and the opportunities to make different deal structures and portfolio for outcomes to get more synergies; the modification of the systems to control and monitor the counterparties' performance seeking the opportunities to transform fixed costs in variable ones by means of the broader application of the project approach and more precise Intellectual property appraisal (Global, 2012).

Further on the Venture Capitalists were to consider the new forms of funding constantly emerging, enabled by new technologies or their derivatives. Thus, the investment organization selection principles ceased to be constant. With respect to the fund structures it 
meant that they could be evergreen or closed-end, depending on the case.

The new capital demand imperatives stipulated another class of investors, - flexible wealthy persons with longer investment horizons, family offices, endowments, crowdfunding platforms, etc., which complemented the renewed participants of the sector such as business angels, governmental agencies, commercial banks, leasing or factoring companies, trade creditors (suppliers), corporate institution, innovation infrastructure entity, etc.

The changes in the market and the proliferation of its stakeholders favored the new criteria of venturing evaluation different from its contribution to the innovations production in a traditional sense but that of a new job creation as the 'mice' businesses do and other social need satisfaction. The funding patterns of these be it in form of equity, debt (venture) or others and the competences required they transfer are out of the traditional VC institutes and organizations. Still since they contributed to the efficient solution to the "basic problem of entrepreneurial finance" they were worth to be included in the sector and analyzed in frame of its self-correcting mechanism of reproduction and development (Block \& Sandner, 2011).

Such a theoretical recognition of the new aspects of VC sector was formulated in terms of the "new venture creation" which stated a more holistic view over the phenomenon. Thus the VC sector was conceptualized in lens of its evolution distinguishing between the "fundamental", "traditional" or "original" VC model and the new one or the "current" VC model.

Since the first one was to be limited to the fundbased VC investments the new model qualified as an "innovation capital" (IC) resulted much more complex. Its main features were the broadening of the scope of financing sources; the increase of the institutional frames in which its subjects operate; the transition to a more creative than the previous business (and financial) model reducing the start-ups' dependence on traditional VC funds in favor of technology platforms and others networks as a source of funds - all to ensure the efficiency of the capital flow increase. To sum up the Venturing look to evolve to become an overall economic ecosystem.

These qualitative aspects were complemented with the attempts to measure the new type of capital and to form its metrics. One of the contributions was that of the Russian venture company's joint research report.
Table 4: Sources of Innovation Capital in USA and Europe, bIn USD

\begin{tabular}{|c|c|c|}
\hline Type of capital & USA & Europe \\
\hline \hline Loans & 312,6 & 792,2 \\
\hline Corporate R\&D & 214,2 & 179,6 \\
\hline Friends and Family & 207 & 93,5 \\
\hline Public R\&D & 115 & 57 \\
\hline Enterprises & 33,1 & 7,4 \\
\hline State Warranties \& Sponsorship & 30 & 73,4 \\
\hline Crowd & 9,5 & 3,3 \\
\hline Business-angels & 19,2 & 6,1 \\
\hline Collateral & 5,6 & 40,1 \\
\hline Total & $\mathbf{9 4 6 , 2}$ & $\mathbf{1 2 5 2 , 6}$ \\
\hline
\end{tabular}

Source: (Kommertsyalizatsiya, 2015).

The advantages of the data of the Table 4 are that they pretend detailing the variety of funding forms of the entrepreneurial innovative activity treated it in a broad sense, i.e. with the contribution of various subjects and vectors included.

This is the case, for example, of corporate venturing which until recently has been a little-noticed, as judged by traditional databases against is as an important element of the VC market nowadays.

Some of the features mentioned were apprised by the Russian scholars, analyzed in the respective research and became the object of political efforts. However, the contribution is not enough mainly due to the limitations of the Tables 4' content.

Following the clauses content the approach doesn't follow some strict criteria by means of which the R\&D funding is integrated in the venturing processes, as well as the reasons to omit the traditional funds and funding institutes, and the means to overcome the problems with the intersection of the flows double accounting under the modern digital and social networking.

The info omits also some specific parts of capital transfer in form competences valuable for the vast majority of small and young companies as the main consumers and stakeholders of the VC operations. To apprise their performance and to impact them efficiently one needs to have a broader and more nuanced information of the them.

In view of the above a more holistic understanding of the VC evolution and the respective presentation of 
its information requires to be structured in a way to reveal the following aspects:

- the links between various capital-competence sources and firm development;

- $\quad$ the info about the modes of international startup firm investing and possible effects of them

- $\quad$ a venturing performance of different VC subjects such as corporate' and universities' funds to support spinouts and students' start-ups, as well as their networking in various entities and regions to provide an efficient solution to the "basic problem of entrepreneurial finance";

- the data of the correlation between time and amount of funding and competences on one side and the firm's performance on the other;

- $\quad$ the geography (international and no) of exits, of their different forms including;

- $\quad$ the links between the small and large VC funds to balance the investments in portfolio companies of various stages (Series A, B and onward) as well as the bridge between the VC and other entities (the private equity, etc.);

- $\quad$ the skills of large VC funds' GP;

- the competences provided to the founders to help them to scale their companies;

- $\quad$ the engagement of large corporations in the VC ecosystem support;

- the international/global connectivity networks of the companies and the VC to establish partnerships with start-ups and up to established corporate research centers.

Such large an information overcomes the traditionally laconic forms of key indicators, from which we parted at the beginning of the article. Still the importance to comprehend and conceptualize the state of the evolution of VC and its practical consequences requires a more detailed analysis and its visualization.
An efficient solution of it may be obtained by means of an international project not limited with the national framework and its particularities but to provide a holistic overview of the actual tendencies of the VC evolution and its options of become an effective international ecosystem.

\section{REFERENCES}

Block, J. H. and P. Sandner (2011). Venture capital funding in the middle of the year 2011: Are we back to pre-crisis boom levels? Strategic Change, 20(5-6), 161-169.

Block, J. and P. Sandner (2009). What is the effect of the financial crisis on venture capital financing? Empirical evidence from US Internet start-ups. Venture Capital, 11(4), 295-309. https://doi.org/10.1080/13691060903184803

Canada's Venture Capital Landscape: Challenges and Opportunities June 2017.

Global venture capital insights and trends report 2011 EY 2012.

Gobry, P.-E. (2011, Nov 02). The way companies are getting financed is completely changing. Business Insider $\mathrm{BI}$ Research. Retrieved from http://articles.businessinsider.com/ 2011-11-02/research/30349316_1_crowdfunding-investorsand-startups-kickstarter

Greene, J., D. Purcell, B. Edelman, D. Giordano, R. Ruback, D. Mihas, T. Opler, T. Cahill and G. Giovannetti (2010). The role of private equity in life sciences. Journal of Applied Corporate Finance, 22(2), 8-35.

Kedrosky, P. (2009). Right-sizing the US venture capital industry. Venture Capital, 11(4), 287-293. https://doi.org/10.1080/13691060903190255

Kommertsyalizatsiya technologii na ranney stadia. Issledovaniye globalnikh practik: Universitety, Corporatsii, Gosudarstvo. RVC, Kaufmann Fellows, Tilburg University 2015.

Mason, C. (2009). Venture capital in crisis. Venture Capital, 11(4), 279-285. https://doi.org/10.1080/13691060903303775

RVCA Yearbook 2017 RF, RVCA, 2017.

Moreva E. (2012a) The problems of the small business evolution in innovations: USA for RF // TRANSPORT BUSINESS IN RUSSIA, №6-2, pp.47- 51.

Moreva E. (2012b) The Problems of small and medium production development: the Mexican practices for Russia // Gorisonti economiki, № 5, pp.56-58.

Moreva E. (2013) Innovation problems of the entrepreneurs in a developed economy (the Canadian case) // TRANSPORT BUSINESS IN RUSSIA, №3, pp.32- 35.

Segalla, M., D. Rouzies and J. Ghalbouini (2010). The venture capital industry's crisis: A problem of management and marketing - Not finance? Working paper. HEC.

Sukharevskaya A. Infografika: venchurnuye investitsii 2017 goda https://incrussia.ru/understand/infografika-venchurnyeinvestitsii-2017-goda/

Wilson, F. (2009). The venture capital math problem. Fred Wilson's blog AVC. Retrieved from http://www.avc.com/a_vc/2009/04/ the-venture-capital-math-problem.html

\section{DOI: https://doi.org/10.6000/1929-7092.2018.07.82}

(C) 2018 Eugenia L. Moreva; Licensee Lifescience Global.

This is an open access article licensed under the terms of the Creative Commons Attribution Non-Commercial License (http://creativecommons.org/licenses/by-nc/3.0/) which permits unrestricted, non-commercial use, distribution and reproduction in any medium, provided the work is properly cited. 